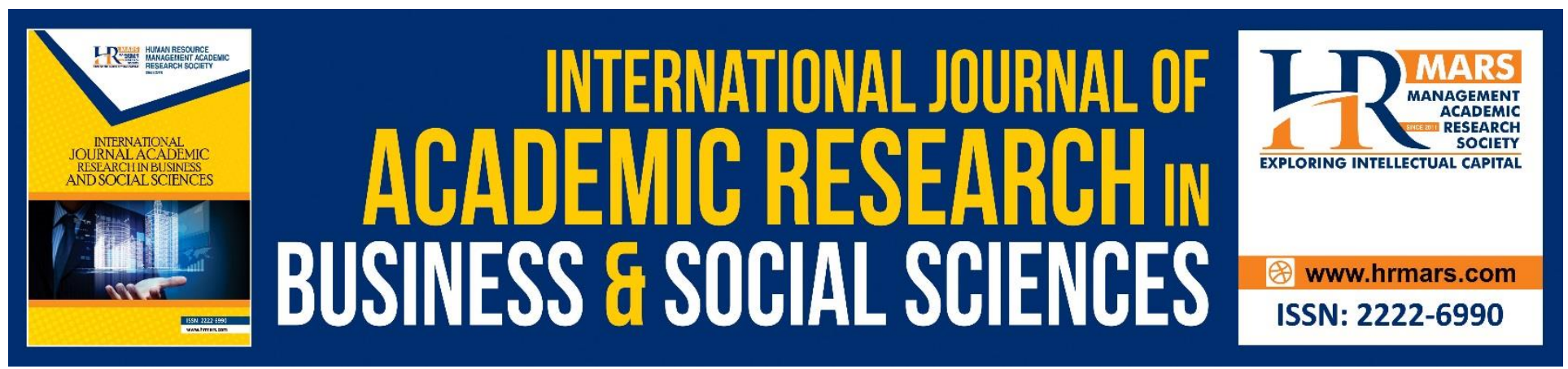

\title{
Press Freedom and Development Indicators: A Panel Data Study
}

Florescu Decebal Remus, Napoca Romania, Cuceu lonuț Constantin

To Link this Article: http://dx.doi.org/10.6007/IJARBSS/v9-i3/5794 DOI: 10.6007/IJARBSS/v9-i3/5794

Received: 01 Feb 2019, Revised: 19 Feb 2019, Accepted: 26 Feb 2019

Published Online: 21 March 2019

In-Text Citation: (Remus, Romania, \& Constantin, 2019)

To Cite this Article: Remus, F. D., Romania, N., \& Constantin, C. I. (2019). Press Freedom and Development Indicators - A Panel Data Study. International Journal Academic Research Business and Social Sciences, 9(3), 1281-1290.

\section{Copyright: (C) 2019 The Author(s)}

Published by Human Resource Management Academic Research Society (www.hrmars.com)

This article is published under the Creative Commons Attribution (CC BY 4.0) license. Anyone may reproduce, distribute, translate and create derivative works of this article (for both commercial and non-commercial purposes), subject to full attribution to the original publication and authors. The full terms of this license may be seen at: $\underline{\text { http://creativecommons.org/licences/by/4.0/legalcode }}$

Vol. 9, No. 3, 2019, Pg. 1281 - 1290

http://hrmars.com/index.php/pages/detail/IJARBSS

JOURNAL HOMEPAGE

Full Terms \& Conditions of access and use can be found at http://hrmars.com/index.php/pages/detail/publication-ethics 


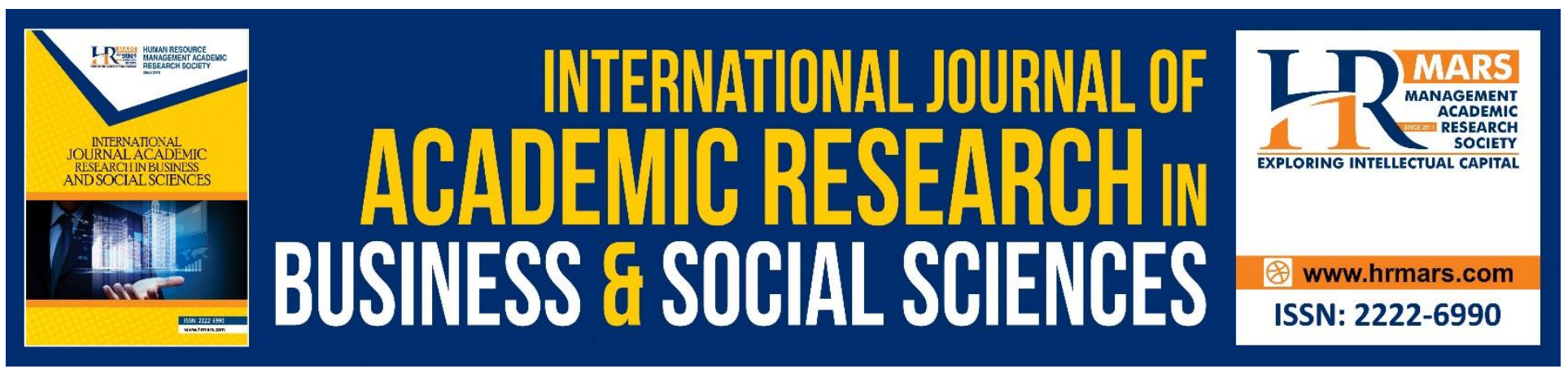

\title{
Press Freedom and Development Indicators: A Panel Data Study
}

\author{
Florescu Decebal Remus \\ Faculty of Political, Administrative and Communication Sciences, "Babeș-Bolyai” University Cluj \\ Napoca, Romania \\ Email: remus_florescu@yahoo.com
}

\section{Cuceu lonuț Constantin}

Faculty of Economics and Business Administration, "Babeș-Bolyai" University Cluj-Napoca, Romania Email: cuceuionut@yahoo.com

\begin{abstract}
The purpose of our paper is to study the correlations between the freedom of a country's press and several development indicators of states, covering their economic dimension, the inequalities among their population, their educational system, their healthcare domain and governance quality, expressed as control of corruption. Working with an unbalanced panel data set for 196 countries for the 2000-2017 time period, our results support the idea that the higher the development of a country is, expressed through a higher per capita gross domestic product, less disparities among its population layers, better educational and healthcare indicators, a wider Internet usage and less corruption for its government, then the more freedom its media has.
\end{abstract}

Keywords: Freedom of Press, Corruption, Education, Healthcare, Panel Data Regressions

\section{Introduction}

The idea of our study starts from a Thomas Jefferson quotation: „No government ought to be without censors; and where the press is free no one ever will". Being one of the founding fathers of the United States of America, Thomas Jefferson's words from the beginning of the XIX century express now, after more than 200 years of evolution of mankind, one of the most important principles of democracy. Press, the fourth power of the state, is still the most important instrument that holds the government accountable for its actions. We ask ourselves what happens with a government without the "censorship" of the press: corruption flourishes, economy stagnates, poverty spreads endemically across the population, education, healthcare and the security of the people provided by the state cannot ensure a prosperous future of the nation. 
The digital era came with one of the greatest challenges free press is facing in the history of mankind. In a time when fake news campaigns are easier to conduct than ever before and their effects are more severe than ever before - ranging from influencing the results of the democratic elections till starting conflicts that can lead to incommensurable casualties - people need to realize that without free press, not only the bases of democracy, but also the wellbeing of the nations, are in great danger.

\section{Literature Review}

A great strand of literature has been allocated towards studying the impact the freedom of the media has upon different facets of development in a broad sense. Some studies focus on the causality relationship between the freedom of the press and different variables that reflect human development (ranging from poverty to inequalities), healthcare, education, governance or security. Besides this focus for validating the (bi) directionality of the relationship between the freedom of press and several development indicators, there exist studies that use the freedom of press as an explanatory variable. Some papers study the interactive association of press freedom, access to media and education, with a nation's corruption levels (Dutta \& Roy, 2013). A country's score for corruption, as provided by the International Country Risk Guide database, an index that ranges from 0 to 6 , with higher values signifying a less corrupt country, is modelled through an extensive panel of 151 developed and developing countries over the period 1995-2008. Corruption is explained by press freedom, access to media and educational attainment as its explanatory variables, plus their interaction. This paper concludes that higher press freedom, higher access to media and higher education together are related to lower levels of corruption (Dutta \& Roy, 2013). Then, some other studies use the freedom of the press as an explanatory variable for conflict in 146 countries (Das \& DiRienzo, 2014). Using the 2012 Peace and Conflict Instability Ledger data (PCI), published by the Center for International Development and Conflict Management for measuring conflict at the country level, they empirically test the underlying factors that lead to wars and adverse regime changes, mainly the freedom of press index published by Freedom House, through linear and polynomial models. Their control variables cover democracy, diversity, education, geographic characteristics and economic development. Their results indicate that the relationship between conflict and press freedom is best described as nonlinear: conflict is minimized at both the unrestricted and restricted ends of the press freedom spectrum and reaches a maximum at an intermediate level of press freedom.

On the other hand, there are studies that strive to explicit the freedom of the press through several other independent variables, which is the purpose of our study as well. Researchers explore the role of press freedom in the very idea that a free and open press does increase economic growth (Abdullah \& Syed, 2013). Their study analyses the relationship between media freedom, foreign direct investment, and economic growth using balanced panel data that include 115 states over the 2002-2010 time period. Their collected data includes the following variables: the press freedom index by Reporters Sans Frontières, the per capita gross domestic product, net inflows of foreign direct investments and nevertheless, for robustness checks, the press freedom index of Freedom House. Their paper estimates the causal relationship between press freedom, economic growth and foreign direct investments. Their results support the existence of a bidirectional relationship between press 
freedom and economic growth, using the generalized method of moment's technique. Basically they prove the bidirectional causalities between press freedom and economic growth, indicating that the freedom of press plays a vital role in the development of the economy and the reverse relationship points out that an economically growing country implements additional press freedom.

Some other researches empirically test the negative influence of corruption upon the freedom of media (Solis \& Antenangeli, 2017). This paper analyzes this relationship on both traditional media (print and broadcast, from 1960 to 2015) and new media (Internet, from 1993 to 2015). Using panel structured data and the ordinary least squares (OLS) technique, they test the hypothesis that higher levels of executive corruption are associated with greater efforts of censoring the media. The set of dependent variables includes governmental attempts to censor different types of media, further estimated by considering the executive level corruption as an independent variable and several control variables. Their control variables include an educational dimension (secondary school enrollment variable), political and democracy control variables and a proxy for the country's wealth (World Bank's GDP per capita). Their results suggest that as governments become more corrupt, governmental efforts to censor both forms of media are likely to increase, i.e. executive-level corruption is associated with greater levels of government attempts at censoring the media, for both traditional print and broadcast media as well as new media. By further examining if this relationship holds for stratified subsamples of their data, among different world regions and regime types, they obtain overall confirmation of their research hypothesis (Solis \& Antenangeli, 2017).

Nonetheless, a UNESCO 2008 report has been of major interest for our study, because it analyzes the correlations between freedom of the press and the different dimensions of development, poverty, governance and conflict (Guseva et al, 2008). Their report starts from the idea that the influence of a free press has never been properly assessed because it is difficult, if not impossible to calculate such impact. Working with simple econometric regressions, they test the correlations between the freedom of the press and different dimensions of the societies. In their study, the freedom of press index published by Freedom House is directly explicated by the Gini index and indirectly explicated by monetary poverty, health status variables, educational proxies and control of corruption. They conclude that by promoting freedom of the press, countries provide themselves with a powerful development tool, idea that we also support and will try to validate through our present study.

\section{Data and Research Methodology}

This study uses World Bank available data for 196 countries, detailed in Appendix 1. The data cover the 2000-2017 time interval. The total number of observations is of 3528 , covering the widest possible span of high-income to low-income worldwide countries. Modelling is applied to an unbalanced panel data structure.

The dependent variable is the Freedom of the press $\left(\mathrm{FP}_{\mathrm{it}}\right)$ analysed by Freedom House in its annual Freedom of the Press (FOTP) survey (available from the year 1980 on). The countries are ranked on a scale from 0 to 100 , with the countries with the freest media scoring close to 0 . Basically, the higher the score, the less freedom the press has in that country. The status of countries may be that of Free for scores between 0 and 30, Partly Free for scores between 31 and 60 and Not Free for countries with their FP score above 61. According to the data provided by the 2016 Freedom House 
rankings, about $30.65 \%$ of worldwide analysed countries are Free, 33.16\% are Not Free and $36.19 \%$ are Partly Free, so the distribution of countries on these three categories is rather uniform.

The independent variables considered by the present study cover indicators from the fields of economics, healthcare, education and governance. From the economic development point of view, our regressions use the GDP per capita of countries (GDPpercapitait), provided by the World Bank Group (2019), i.e. the gross domestic product divided by midyear population, in current U.S. dollars for each country. Moreover, for illustrating the inequalities between countries, we also used their Gini index as a human development indicator, downloaded from the World Bank. The Gini coefficient ( Gini $_{i t}$ ) is probably the most commonly known measure to represent the income or wealth distribution of a nation's residents. If all people have non-negative income (or wealth, as the case may be), the Gini coefficient can theoretically range from 0 (complete equality) to 1 (complete inequality). We use it as expressed in percentages ranging between 0 and 100.

For the health dimension of countries, we use World Bank data on Life Expectancy at birth ( $L E_{i t}$, number of years for the entire population), the Infant mortality rate and the Immunization rate for measles. The infant mortality rate (Mortalityit) represents the number of infants dying before reaching one year of age, per 1,000 live births in a given year $t$ and a given country $i$. The immunization rate for measles (Immunization ${ }_{i t}$ ) measures the percentage of children ages 12-23 months who received the measles vaccination before 12 months or at any time before the survey. A child is considered adequately immunized against measles after receiving one dose of vaccine. We chose this particular immunization rate because although most people are familiar with the rash and fever associated to this disease, if the real virus is contacted, specialists sustain that this particular disease can lead to long-term or even lifelong effects. Moreover, according to a USA recent Center for Disease Control and Prevention report, from 2016 to 2017, the number of measles cases increased by 31\% worldwide (Dabbagh et al, 2018).

For covering the educational dimension, we used two indicators provided by the World Bank: the number of years of Compulsory Education in each country and the Completion Rate.

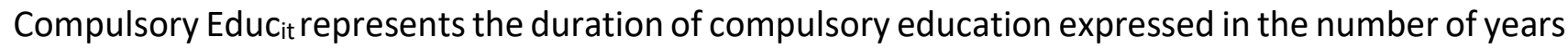
that children are legally obliged to attend school in a given country i. For the completion rate educational indicator (CompletRate ${ }_{i t}$ ) this study uses the lower secondary completion rate, total (\% of relevant age group) in each country. World Bank's CompletRate it $_{\text {it }}$ measured as the gross intake ratio to the last grade of lower secondary education (general and pre-vocational), simply calculated as the number of new entrants in the last grade of lower secondary education, regardless of age, divided by the population at the entrance age for the last grade of lower secondary education.

Governance is reflected through a set of indicators that World Bank Governance Indicators Databank provides for political stability, institutions and legal system. Out of these, we picked the Control of Corruption indicator $\left(\mathrm{CC}_{i t}\right)$ that captures perceptions of the extent to which public power is exercised for private gain, including both petty and grand forms of corruption, as well as "capture" of the state by elites and private interests. Using data from various different sources, World Bank estimate gives the country's score on the aggregate indicator, in units of a standard normal distribution, i.e. ranging from approximately -2.5 to 2.5 . We expect a strong relationship to exist between corruption and press freedom of countries, because the higher the perceived corruption levels are, the lower the freedom of media within a country and thus the higher its FP score. 
This study also uses the Individuals using the Internet (\% of the total population of a country) dependent variable. InternetUsage ${ }_{i t}$ accounts for the percentage of individuals out of the total population of a country $i$ in year $t$ that have used the Internet (from any location) in the last 3 months. The Internet can be used via a computer, mobile phone, personal digital assistant, digital TV or others, most probably for keeping up the pace with the worldwide news, contacting friends and so on.

Table 1. Summary Statistics, using the observations 1:01 - 196:18

(Missing values were skipped)

\begin{tabular}{llllll} 
Variable & Mean & Median & S.D. & Min & Max \\
FP & 46.9 & 47.0 & 24.3 & 0.000 & 100. \\
GDPpercapita & $1.26 \mathrm{e}+004$ & $3.96 \mathrm{e}+003$ & $2.11 \mathrm{e}+004$ & 111. & $1.85 \mathrm{e}+005$ \\
Gini & 37.9 & 35.8 & 9.05 & 16.2 & 64.8 \\
LE & 69.2 & 71.6 & 9.21 & 38.7 & 85.4 \\
Mortality & 29.6 & 19.3 & 27.2 & 1.60 & 142. \\
Immunisation & 85.8 & 92.0 & 15.3 & 8.00 & 99.0 \\
CompulsoryEduc & 9.24 & 9.00 & 2.11 & 4.00 & 16.0 \\
CompletRate & 72.5 & 81.9 & 27.8 & 3.82 & 208. \\
CC & -0.0645 & -0.307 & 0.999 & -1.87 & 2.47 \\
InternetUsage & 29.0 & 18.4 & 28.4 & 0.000 & 98.2 \\
& \multicolumn{5}{c}{ Source: Authors' processing }
\end{tabular}

Table 1 presents the summary statistics for the freedom of press as the dependent variable and the independent variables used in this study, while their correlation coefficients are found in Appendix 2.

The FP variable is scaled on a range from 0 to 100. Although methodological changes have been made periodically with each edition of the survey, the current score distribution scale (used from 2002 on) accounts for the legal, political and economic environments. The maximum score of 100 was reached in 2000 by Iraq, Myanmar and North Korea, for the worst oppression of media. Among the 2017 FP scores, the best results are obtained by Norway (8), Sweden (11), Belgium and Finland (12), as having the highest freedom of the press.

For the human development indicators, we may notice the high disparity that exists between the most recent available data of the per capita GDP of countries: there exist countries whose per capita GDP is less than 1000 dollars in 2017 (292 USD in Burundi, 338,48 Malawi, 378,06 Niger and others) while the highest values of par capita GDP are registered in Luxembourg $\left(1.04 \times 10^{5}\right.$ USD) and the northern countries. For the Gini coefficient, the highest disparity was registered in 2005 in South Africa (64.8), with similar values in the years that followed.

From the point of view of the health status variables, there are countries with the most recently reported LE above the age of 80: Austria, Belgium, Canada, Denmark, Finland, France, Hong Kong, Iceland, Israel, Japan, Luxembourg, Spain and many other high-income countries but there also are countries whose LE barely exceed 50 years of age, like Sierra Leone 51.8, Central African Republic 52.2, Chad 52.9, Nigeria 53.4, etc. Then, for the Mortality variable, there are countries with an infant mortality rate below 2 at 1000 live births (Iceland, Slovenia, Finland and Japan, in 2017) and low income African countries where Mortality registers the maximum values of above 80 deaths up to 
the age of 1 out of 1000 live births (Central African Republic 87.6 and Sierra Leone 81.7). The lowest immunisation rate against measles is registered in South Sudan (only 20\% of children in 2017) while the average value of this immunisation rate is $85.8 \%$, many countries reaching the $98-99 \%$ vaccination rate in the recent years.

For reflecting the educational dimension, the number of years of compulsory education of worldwide countries between 2000-2017 ranges from a minimum value of 4 years (Angola 20002006) to a maximum value of 16 years (Venezuela, 2017). The tendency for the entire time period is that of increasing Compulsory Educ for the wide majority of analysed countries.

The control of corruption variable is scaled on a range from -2.5 to 2.5, and in 2017, the lowest value is registered in Afghanistan (-1.82574) and the highest value is registered in Yemen (2.24101).

On average for the studied time period, $29 \%$ of the population of worldwide countries has had internet access. Still, the highest values for the Internet Usage it $_{\text {variable are registered in } 2017 \text { in }}$ Luxembourg (97.82\%).

The paper analyses how much freedom media has for a wide sample of states with the help of simple linear econometric models, by considering Press Freedom FP as an endogenous (dependent) variable. The estimations were carried out using the panel technique and the coefficients were estimated with the ordinary least squares (Pooled OLS) method for panel data.

\section{Results and Discussions}

The estimations reveal the dependency relationship between the FP scores of states and certain independent variables that may be their approximation, according to the data synthesized in Table 2 , through the least squares method for panel data. The default robust estimator is that suggested by Arellano, handling both heteroskedasticity and autocorrelation (the HAC approach). 
INTERNATIONAL JOURNAL OF ACADEMIC RESEARCH IN BUSINESS AND SOCIAL SCIENCES Vol. 9, No. 3, March, 2019, E-ISSN: 222 2-6990 @ 2019 HRMARS

Table 2. The Estimation of Press Freedom,

Pooled OLS, Robust (HAC) standard errors

\begin{tabular}{|c|c|c|c|c|c|c|c|c|c|}
\hline & (1) & (2) & (3) & (4) & (5) & (6) & (7) & (8) & (9) \\
\hline Constant & $\begin{array}{l}52.223 \\
2 \\
* * *\end{array}$ & $\begin{array}{l}21.968 \\
6 \\
* *\end{array}$ & $\begin{array}{l}123.59 \\
2 \\
* * *\end{array}$ & $\begin{array}{l}36.239 \\
7 \\
* * *\end{array}$ & $\begin{array}{l}75.814 \\
4 \\
* * *\end{array}$ & $\begin{array}{l}75.549 \\
0 \\
* * *\end{array}$ & $\begin{array}{l}64.353 \\
5 \\
* * *\end{array}$ & $\begin{array}{l}46.422 \\
6 \\
* * *\end{array}$ & $\begin{array}{l}58.071 \\
8 \\
* * *\end{array}$ \\
\hline $\begin{array}{l}\text { GDP } \\
\text { percapita }\end{array}$ & $\begin{array}{l}-0.000 \\
47^{* * *}\end{array}$ & & & & & & & & \\
\hline Gini & & $\begin{array}{l}0.5234 \\
93 * *\end{array}$ & & & & & & & \\
\hline$L E$ & & & $\begin{array}{l}-1.089 \\
0 * * *\end{array}$ & & & & & & \\
\hline Mortality & & & & 0.3640 & & & & & \\
\hline $\begin{array}{l}\text { Immuni } \\
\text { zation }\end{array}$ & & & & & $\begin{array}{l}-0.334 \\
9 * * *\end{array}$ & & & & \\
\hline $\begin{array}{l}\text { Compulso } \\
\text { ry Educ }\end{array}$ & & & & & & $\begin{array}{l}-3.165 \\
9 * * *\end{array}$ & & & \\
\hline $\begin{array}{l}\text { CompletR } \\
\text { ate }\end{array}$ & & & & & & & $\begin{array}{l}-0.214 \\
6 * * *\end{array}$ & & \\
\hline$C C$ & & & & & & & & $\begin{array}{l}-16.42 \\
4 * * *\end{array}$ & \\
\hline $\begin{array}{l}\text { Internet } \\
\text { Usage }\end{array}$ & & & & & & & & & $\begin{array}{l}-0.391 \\
4^{* * *}\end{array}$ \\
\hline$R^{2}$ & $\begin{array}{l}0.1781 \\
78\end{array}$ & $\begin{array}{l}0.0457 \\
97\end{array}$ & $\begin{array}{l}0.1734 \\
33\end{array}$ & $\begin{array}{l}0.1682 \\
41\end{array}$ & $\begin{array}{l}0.0446 \\
81\end{array}$ & $\begin{array}{l}0.0732 \\
29\end{array}$ & $\begin{array}{l}0.0668 \\
80\end{array}$ & $\begin{array}{l}0.4640 \\
69\end{array}$ & $\begin{array}{l}0.2041 \\
66\end{array}$ \\
\hline $\begin{array}{l}\text { Adjusted } \\
R^{2}\end{array}$ & $\begin{array}{l}0.1779 \\
22\end{array}$ & $\begin{array}{l}0.0448 \\
75\end{array}$ & $\begin{array}{l}0.1731 \\
69\end{array}$ & $\begin{array}{l}0.1679 \\
84\end{array}$ & $\begin{array}{l}0.0443 \\
85\end{array}$ & $\begin{array}{l}0.0729 \\
07\end{array}$ & $\begin{array}{l}0.0663 \\
88\end{array}$ & $\begin{array}{l}0.4638 \\
93\end{array}$ & $\begin{array}{l}0.2039 \\
16\end{array}$ \\
\hline
\end{tabular}

Source: Authors' processing

Note: $* * *$ designates the $1 \%$ significant coefficients, $* *$ designates the $5 \%$ significant coefficients and $*$ designates the $10 \%$ significant coefficients.

The estimation of the simple linear models' parameters is found in Table 2. Regression analysis provides a means of objectively assessing the magnitude and direction (positive or negative) of each independent variable's relationship. The interpretations of these simple regressions are the following:

(1)At an increase of the per capita GDP with 1 USD, the freedom of press score will decrease, on average, with 0.00047 score units, ceteris paribus. This negative relationship is expected, because the lower the FP score, the more freedom media has, given by the economic power of that country. This relationship has also been checked by various studies (Abdullah \& Syed, 2013). 
INTERNATIONAL JOURNAL OF ACADEMIC RESEARCH IN BUSINESS AND SOCIAL SCIENCES Vol. 9, No. 3, March, 2019, E-ISSN: 222 2-6990 @ 2019 HRMARS

(2)At an increase of the Gini Index of a country with 1 unit, the FP score will increase, on average, with 0.5234 units, ceteris paribus. So, the more inequality exists in a certain country, the higher its FP score and thus the less freedom its press has.

(3)At an increase of Life expectancy with 1 year, the FP score will decrease, on average, with 1.09 score units, ceteris paribus. So, for each additional year that LE increases with, the FP score of a country is lower on average by 1.09 score units, thus more freedom for the press.

(4)At an increase of Mortality rates with 1 unit, FP will increase, on average, with 0.364078 units, ceteris paribus. This positive relationship is opposed to the negative one between FP and LE, and indeed, the higher mortality rates are, the higher the FP score and the less power press does have, results reviously validated by the literature (Guseva et al, 2008).

(5)At an increase of the Immunisation rates with 1 percentage point, FP will decrease, on average, with 0.33494 score units, ceteris paribus. The higher the immunisation rates against measles are, thus the healthier the people of a country, the lower the FP score, so more freedom for the media.

(6)At an increase of the number of years of compulsory education with 1 additional year, FP will decrease, on average, with 3.16585 score units, ceteris paribus. The more educated people are, the lower the FP score, so the more freedom for the press.

(7)At an increase of the Completion rate with 1 percent, FP will decrease, on average, with 0.21458 units, ceteris paribus.

(8)At an increase of CC of the company with 1 unit, FP will decrease, on average, with -16.4243 units, ceteris paribus. So the less corrupt a country is, the more freedom its press has. This finding is correlated with previous studies (Solis \& Antenangeli, 2017).

(9)At an increase of internet access rates with 1 percent, FP will decrease, on average, with 0.391361 score units, ceteris paribus. So, the more Internet is used, the more freedom its press has, having a lower FP score within a given country and time moment.

The predictive accuracy of a model is given by its coefficient of determination $\left(R^{2}\right)$, representing the amount of variance in the dependent variable FP explained by the significant independent variable. For example, in model (8), a value of 0.464069 points towards a medium prediction accuracy, and the use of the Adjusted $R^{2}(0.463893)$ as the measure of overall model predictive accuracy is often preferred, being particularly useful in comparing across regression equations involving different numbers of independent variables or different sample sizes because it makes allowance for the degrees of freedom for each model (Hair et al, 2010). Comparing the Adjusted $\mathrm{R}^{2}$ for all these 9 simple regression models, it can be noticed that it takes the maximum value when CC is used as an explanatory variable for FP. Thus, it can be stated that the variable with the highest explanatory power is the control of corruption, because $46.4 \%$ of the variance of FP is explained by CC.

\section{Conclusions}

The development level of a country is, to a certain extent, mirrored by its educational dimension, healthcare system, economic situation, governmental environment and so on. Our paper proves that the freedom of media within a certain country is granted the more educated the people of a country are, the better healthcare indicators there exist, the less corrupt a government is and the higher per capita GDP within that country. 
Our firm results confirm an indirect relationship between the FP scores of countries and their per capita GDP, life expectancy, immunisation rates, number of years of compulsory education, their completion rate, control of corruption and Internet access and a direct relationship between the nations' Gini index and mortality rates. Basically, the lower the FP score of a country, i.e. more freedom for that country's press, the higher its per capita GDP, the longer its people's life expectancy, the higher the immunisation rates, the better its education indicators (a higher completion rate and an increased number of years of compulsory education), the higher the value of the nation's Control of Corruption (meaning less corruption) and the higher the Internet access rates. On the other hand, the lower the FP score of a country, the lower its Gini index (less inequality there is) and the lower its mortality rate.

These correlations are meaningful for the policy makers of countries, and certain policy recommendations can be drawn out of here. The freedom of press has always been extremely important, and it can be granted by a better economic situation, improved healthcare outcomes, a strong educational system and nevertheless, a decreased level of the undesirable corruption phenomena.

Interesting findings might occur on subsamples of high-income and low-income countries, allowing us to draw particularised conclusions. Another future research perspective of ours considers several other independent variables and the testing of causality.

\section{Corresponding Author}

Florescu Decebal-Remus, “Babeș-Bolyai” University Cluj-Napoca, Faculty of Political, Administrative and Communication Sciences, Romania, remus_florescu@yahoo.com, 71 General Moșoiu Street, Cluj-Napoca, 400132, Romania

\section{References.}

Abdullah, A. \& Syed, Z. A. S., (2013). The Role of Press Freedom in Economic Development: A Global Perspective, Journal of Media Economics, Taylor \& Francis, 26:4-20.

Das, J. \& DiRienzo, C.E., (2014) Conflict and the Freedom of the Press, Journal of Economic and Social Studies, 4(1), 91-113.

Dutta, N. \& Roy, S., (2013) Media, Education and Corruption: Investigating the Associations, Economic Affairs, 2013 Institute of Economic Affairs, JohnWiley \& Sons Ltd, p.207-220.

Guseva M., Nakaa M., Novel A.S., Pekkala K., Souberou B. \& Stouli S. (2008) Press Freedom and Development, UNESCO/GEM-Science Po/CPHS - Science Po research project, UNESCO Division for Freedom of Expression, Democracy and Peace, France. www.unesco.org/webworld

Hair, J. F. Jr., Black, W. C., Babin,B. J. \& Anderson, R. E., (2010) Multivariate Data Analysis (7th edition). Pearson Prentice Hall.

Solis, J. A. \& Antenangeli, L., (2017) Corruption Is Bad News for a Free Press: Reassessing the Relationship Between Media Freedom and Corruption, Social Science Quarterly, WileyBlackwell, 98(3), 1112-1137. 